\title{
cDNAs Generated from Individual Epidermal Cells Reveal that Differential Gene Expression Predicting Subsequent Resistance or Susceptibility to Rust Fungal Infection Occurs Prior to the Fungus Entering the Cell Lumen
}

\author{
Michael J. R. Mould, ${ }^{1}$ Tao Xu, ${ }^{1}$ Mary Barbara, ${ }^{2}$ Norman N. Iscove,${ }^{2}$ and Michèle C. Heath ${ }^{1}$ \\ ${ }^{1}$ Department of Botany, University of Toronto, 25 Willcocks St., Toronto, Ontario, Canada M5S 3B2; ${ }^{2}$ Department of Cell \\ and Molecular Biology, Ontario Cancer Institute, 610 University Avenue, Toronto, Ontario, Canada M5G 2M9
}

Submitted 1 April 2003. Accepted 4 June 2003.

\begin{abstract}
As the cowpea rust fungus penetrates the wall of a cowpea epidermal cell, resistant and susceptible plants exhibit different ultrastructural and cytochemical changes within the epidermal protoplast. To examine plant gene expression at this stage of infection, cytoplasm was extracted from individual inoculated or uninoculated epidermal cells before the fungal penetration peg reached the cell lumen. Initial differential colony hybridization screening of an expressed sequence tag library constructed from globally amplified cDNAs generated from the inoculated resistant cells resulted in 80 clones (out of 835) with a differential hybridization pattern. Further slot-blot screening and screening of the amplified cDNAs generated from inoculated or uninoculated, resistant or susceptible cells revealed 28 separate genes, mostly with no matching sequences in the databases, that were up-regulated in response to the growth of the fungus through the wall of resistant or susceptible cells. Five genes, including those coding for $\beta$ - and $\alpha$-tubulin, were found to be down-regulated specifically in inoculated, susceptible cells, and five were specifically up-regulated in inoculated, resistant cells, including a PR-10 homolog and a phenylalanine ammonia-lyase gene. Probing the amplified cDNAs from each cell type for the expression of cell deathrelated genes revealed that an $L L S 1$ homolog (vuLLS1), cloned from cowpea, was up-regulated by infection in both resistant and susceptible cells and that a homolog of HSR203J was differentially up-regulated in resistant cells. These data show that changes in gene expression predicting the subsequent expression of susceptibility or hypersensitive resistance to fungal infection occur prior to the fungus entering the cell lumen.
\end{abstract}

Additional keywords: defense, hypersensitive response, programmed cell death.

One of the most ubiquitous expressions of disease resistance is the hypersensitive response (HR), a localized rapid cell death associated with the restriction of pathogen growth (Goodman and Novacky 1994). In disease-resistant genotypes

Corresponding author: M. C. Heath; E-mail: michele.heath@utoronto.ca.

The first two authors made equal contributions to this work. of host species, the HR typically is controlled by a parasitespecific recognition event involving a gene-for-gene interaction requiring a resistance gene in the plant and a "matching" avirulence gene in the pathogen (Staskawicz 2001). Evidence suggests that the HR is a programmed cell death with some similarity to mammalian apoptosis, but the death process is still poorly understood (Heath 2000).

Rust fungi are a group of economically important plant pathogens that are particularly amenable to the study of the HR. First, they have a biotrophic relationship with their hosts, meaning that they get their nutrients from living cells and there is little cell death in susceptible plants. Therefore, unlike many other types of pathosystems in which cell death occurs during the successful progress of the disease, there is commonly a clear distinction between susceptible plants, in which there is no cell death, and resistant plants, in which the HR occurs (Heath and Škalamera 1997). Second, the first cells to express the HR are those penetrated by the fungus. For the monokaryotic parasitic stage of rust fungi, which is derived from basidiospore infection, these first-penetrated cells are epidermal cells, and the whole infection process and the living plant cell response can be watched by light microscopy (Chen and Heath 1991; Heath et al. 1997). Studies of the cowpea/cowpea rust fungus pathosystem have revealed that, in its host species, the fungus prevents the signaling between the plant cell wall and the protoplast that in other pathosystems results in wallassociated defense responses (Mellersh and Heath 2001). Therefore, investigations of the invaded cell's response to the rust fungus in the cell lumen should not be confounded by responses to cell wall penetration. Cytological studies have also revealed that differential cytoplasmic events predicting the resistance or susceptibility of the epidermal cell can be detected while the fungus is within the epidermal wall and before it reaches the cell plasma membrane. Such events include an increase in cytosolic calcium levels in the resistant cell $\mathrm{Xu}$ and Heath 1998), ultrastructural signs of an increase in transcription and translation in the resistant cell, and signs of a decrease in translation in the susceptible cell (Mould and Heath 1999). This stage in the infection process can be detected in living cells by the presence of the plant nucleus at the penetration site, since the nucleus moves away as soon as the fungus reaches the plant plasma membrane (Heath et al. 1997).

The present investigation was designed to examine the changes in gene expression that apparently prepare the cowpea 
epidermal cell, while the fungus traverses the cell wall, for subsequent resistance or susceptibility to the cowpea rust fungus. Since infection is asynchronous and multicelled leaf samples would contain cells at different infection stages as well as uninfected cells of various types and activities, we examined plant gene expression solely within the infected epidermal cell by constructing an expressed sequence tag (EST) library using globally amplified DNAs generated from RNA isolated from cytoplasm extracted from single cells. From this library, we identified i) genes that are up-regulated in response to the wall penetration process itself, ii) genes that are up-regulated in resistant cells prior to the expression of the HR, and iii) genes that are down-regulated in susceptible cells, presumably as a prelude to susceptibility. We have also exploited the globally amplified cDNAs from inoculated and uninoculated, resistant or susceptible cells, to probe for the expression of genes suggested to be involved in the HR in other systems.

\section{RESULTS}

As illustrated in Figure 1, individual midvein epidermal cells in inoculated tissue were selected by the presence of the plant nucleus at the penetration site (indicative of the fungus growing within the plant wall prior to reaching the plant plasma membrane), and their cytoplasm was extracted as close to the fungal penetration site as possible without disturbing the fungus or resulting in damage to the neighboring epidermal cells and underlying cortical cells.

Because of the exceedingly small amount of RNA available for reverse transcription and the necessity of not prejudging one or more potentially differentially regulated genes, a reverse transcription-polymerase chain reaction (RT-PCR) technique was used that has been optimized for experiments at the single cell level (Brady and Iscove 1993) and has been confirmed by DNA microarray analyses to preserve the relative abundance of

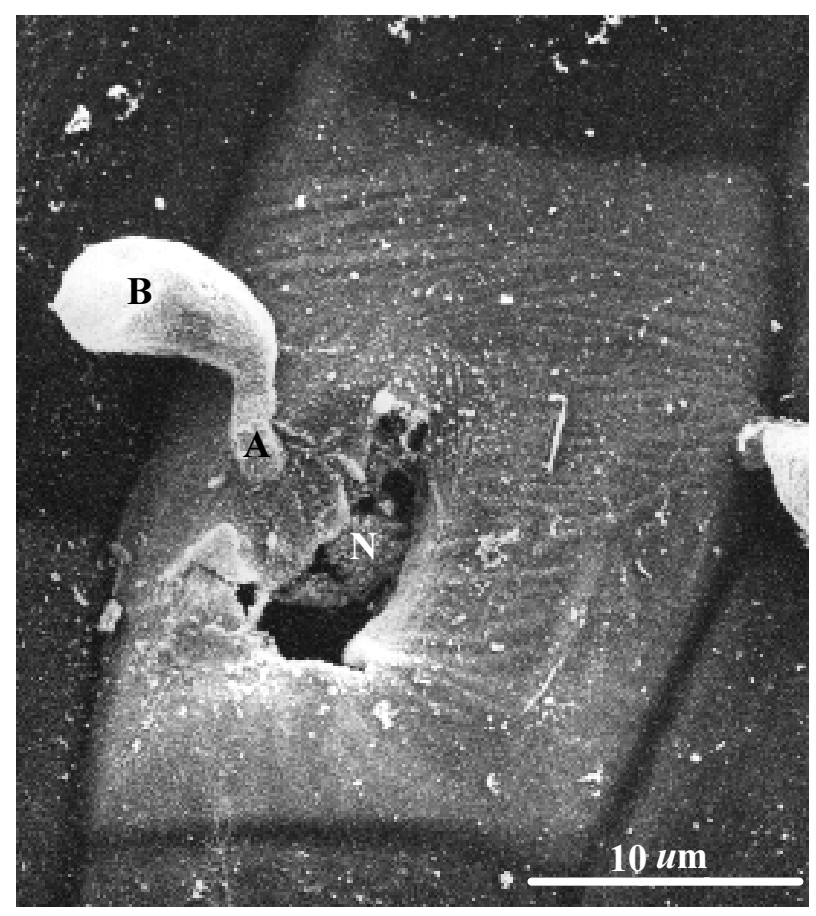

Fig. 1. Scanning electron micrograph of a cowpea rust-inoculated cv. Dixie Cream midvein epidermal cell that was selectively extracted with a microneedle. The nucleus $(\mathrm{N})$ of the plant cell was situated beneath the fungal penetration peg (not visible) produced from the appressorium (A), which was attached to the fungal basidiospore (B) via the germ tube. Scale bar $=10 \mu \mathrm{m}$. all transcripts present in the transcript pool (Iscove et al. 2002). Globally amplified RT-PCR products generated from the microcapillary-extracted cells ranged in size from approximately 100 to $500 \mathrm{bp}$.

\section{First round colony screening}

for differentially expressed genes.

Arrayed colonies (835) harboring a plasmid with confirmed insert DNA from inoculated rust-resistant cells were differentially screened with labeled, globally amplified RT-PCR product generated from either inoculated susceptible, inoculated resistant, or uninoculated resistant epidermal cells. Of the 80 colonies that showed a differential hybridization pattern, 52 gave a strong signal when probed with labeled RT-PCR product from either of the inoculated cell types, while 18 gave a comparatively weaker signal in relation to the probe from the inoculated susceptible cells. Ten colonies showed a strong signal only with the probe generated from the inoculated resistant cells. Sequencing and pair-wise CLUSTALW alignment data indicated that some clones were present in the library in multiple copies.

\section{Second round of screening using slot-blot analysis.}

Hybridization patterns for particular clones identified from the differential screening of the colony arrays were retested in a second screening procedure, the results of which are shown in Figure 2.

To be able to compare differentially expressed genes with those that were expressed at a steady-state level, several clones that gave a strong but nondifferential hybridization signal to all probes were also included in the second round of screening (Table 1). These clones included genes putatively encoding for proteins, such as a cationic peroxidase 2 (clone 6-78), a B12Dlike protein of unknown function (clone 4-54), the DNA-binding protein histone $\mathrm{H} 3$ (clone 1-24), and a potentially novel gene (clone 6-14). As shown in Figure 2, seven of the 15 clones that had been initially classified as being suppressed in susceptible-inoculated cells gave a strong hybridization signal with the probe from the inoculated susceptible cells. These were the gene for a putative 14-3-3-related protein (clone 6-1), a gene for a putative actin-binding protein, profilin, (clone 166), genes related to auxin activity (clones 6-55, 6-120, and 551 ), the gene for a chloroplast outer envelope membrane protein (clone 4-45), and clone 1-118 for which BLAST searches against the various Glycine max ESTs gave sequence similarity matches to the histone $\mathrm{H} 3$ gene. Therefore, from this secondary round of screening, only seven clones were classified as representing genes with suppressed expression in susceptible-inoculated cells (Table 1 and Fig. 2). BLAST search results indicated that these clones showed sequence similarity to genes encoding the cell wall expansion-related protein expansin (clone 6-29), a receptor kinase-like protein (clone 1-7), a nucleotide sugar epimerase (clone 6-100), an endotransglycosylase-related protein (clone 7-55), the putative translation initiation factor SUI1 (clone 5-114), and the cytoskeletal proteins $\beta$ - and $\alpha$ tubulin (clones 6-119 and 6-77, respectively). For clone 6-54, BLAST searches against its best matching G. max EST (GenBank accession number BG406304, for a floral meristematic mRNA) identified this clone as matching the $3^{\prime}$ untranslated region (UTR) for a endo-1,4- $\beta$-glucanase (i.e., cellulase) gene.

Of the 28 unique clones from the first round of screening that represented genes tentatively up-regulated in both inoculated resistant and susceptible cells in comparison to uninfected resistant cells, 12 were included in the second round of screening, and their classification did not change (Fig. 2, clones sequentially from 4-76 to 1-48). BLAST database searches revealed matches for only three clones, clone 1-71 en- 
coding for ribosomal protein L-32, clone 4-35 encoding an RNA-binding protein, and clone 5-72 encoding for a low temperature/salt-response protein (Table 1). Except for clones 1-38 and 4-35, little variation existed between the inoculated cell types regarding the hybridization band intensity values per clone (Fig. 2).

Five of the six unique clones originally identified as representing genes tentatively up-regulated only in the inoculatedresistant cells retained their categorization in the second round of screening (Fig. 2 and Table 1). Two of these unique clones represented plant defense-related genes, namely a cowpea pathogenesis-related (PR) protein of family 10 designated SI-1 (clone 1-85) and a phenylalanine ammonia-lyase (PAL) (clones 3-24, 3-29, and 1-121). All three copies of the PAL clone gave nearly identical hybridization patterns, as indicated by the band intensity values (Fig. 2). Of the other three unique clones within this category, clone 1-124 contained insert DNA for the $3^{\prime}$ region of the gene encoding arginosuccinate synthetase. BLAST searches indicated that both clones 1-119 and 7-50 were partial sequences for genes encoding for prenylated proteins. When translated in the +3 reading frame, nucleotides 3 through 56 of clone 1-119 generated the amino acid sequence APPPQIFSDENPNACSVM, the last four residues being the carboxy-terminus CaaX-box for a putative metal-binding protein, with a UGA stop codon being present at nucleotide 57. Unfortunately, not all of the 3' UTR for the clone 1-119 gene was available for searching due to the EcoRI restriction site present at nucleotide 212, and BLAST searches against all portions of the available $3^{\prime}$ UTR yielded no further information. Also, BLASTX searches using the available 5' coding portion of the clone 1-119 matching G. max EST (GenBank accession number 13789928) failed to reveal any further information regarding the clone 1-119 gene identity. For clone 7-50, translation of nucleotides 3 through 35 in the +3 reading frame generated the amino acid sequence AKKTNQCCTIL, the last four amino acids being the carboxy-terminus CaaX-box, with a UAA stop codon present at nucleotide 36 . Given the $81.25 \%$ sequence identity between the $3^{\prime}$ UTR for clone 7-50 and the available 3' UTR of its matching G. $\max$ EST (GenBank accession number 8669809), further BLASTX searches against the available $5^{\prime}$ coding portion of the $G$. max EST were performed and returned matches to an Arabidopsis putative v-SNARE protein (GenBank accession number 15242933).

\section{Third screening against globally amplified \\ RT-PCR products from all four cell types.}

To further confirm the results from the initial two rounds of differential screening, the globally amplified RT-PCR products from all four cell types, amplified through only two rounds of PCR, were screened using the labeled insert-bearing plasmid DNA from the individual selected clones as probes, as shown in Figure 3. Equal loading was confirmed by visual inspection and image analysis of the ethidium bromide-stained gels and by probing the membranes with the labeled clone 6-55 for the constitutively expressed gene encoding a putative auxinrepressed protein. For clones representing potential differentially expressed genes, a true difference in the hybridization intensity between the four cell types for the given clone probe was accepted when the intensity value for the band with respect to a particular cell type was at least twice that of the comparative cell type. Using this criterion, the results supported the conclusions, from the second round of screening, that fungal infection did not trigger the differential expression of genes encoding a 14-3-3 protein (clone 6-1) or histone H3 (clone 1-24).

By including the material from the susceptible-uninoculated cells in the third screen, the cultivar-specific expression of the selected genes could be examined. Clones 6-29 (expansin) and 1-7 (receptor-like protein kinase) were originally categorized as being suppressed in infected susceptible cells but this third round of screening indicated that both of these genes were ex-

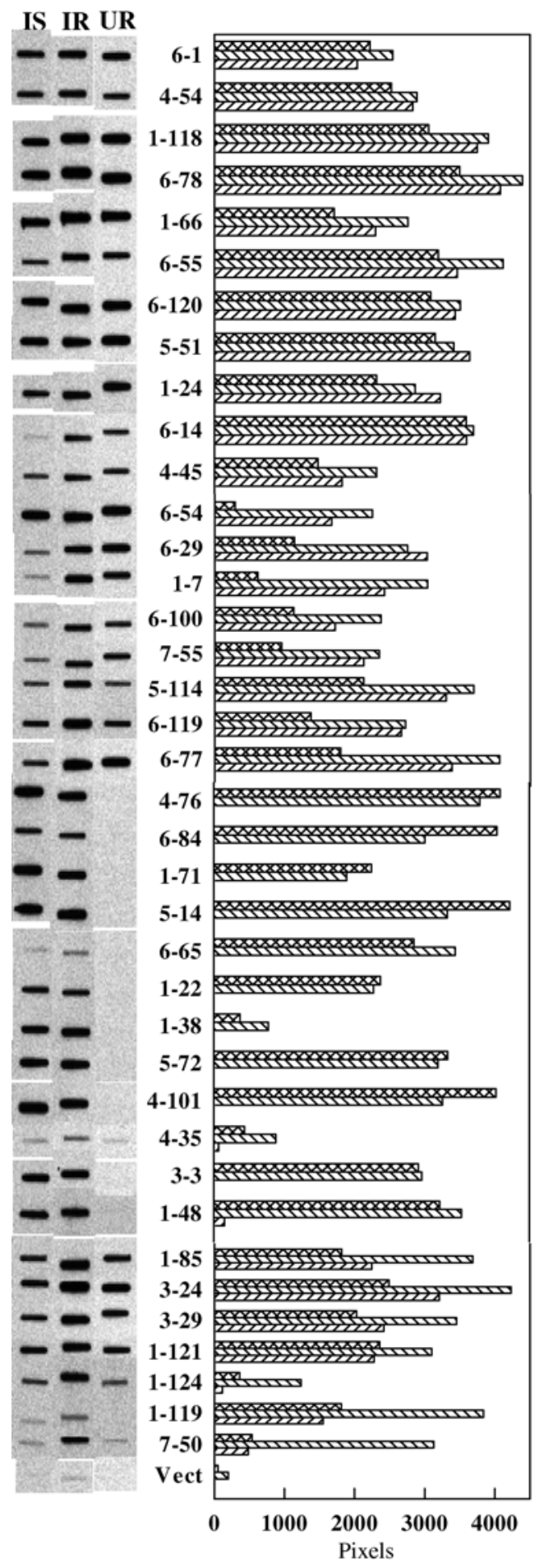

Fig. 2. Slot blots of second-round screening results for clones selected from the initial colony hybridization experiments. Clone numbers are denoted to the right of the band columns. IS = membrane hybridized with probe from cowpea rust-inoculated $\mathrm{CB}$ cells, $\mathrm{IR}=$ membrane hybridized with probe from cowpea rust-inoculated cv. Dixie Cream (DC) cells, and UR $=$ membrane hybridized with probe from uninoculated DC cells. Band intensity value for each slot was determined by using the line scan function of the Northern Eclipse image analysis software. Absolute intensity values, from which the film background value had been subtracted, are shown. $\mathrm{xxx}=\mathrm{IS}$ probe lane, IIII = IR probe lane, and IIII = UR probe lane. 
pressed at a comparatively lower level in susceptible cells regardless of fungal inoculation when compared with levels in the resistant cultivar. The clone 1-7 gene may, however, warrant further investigation regarding its regulation in a compatible interaction, as, although the densitometric value for the band in the inoculated susceptible lane was quite low, it was nearly twice that for the band in the uninoculated susceptible lane (Fig. 3).

Apart from the clones 6-29 and 1-7 discussed above, all five of the remaining unique clones (6-100, 7-55, 5-114, 6-119, and 6-77) identified from the second round of screening as genes that were suppressed in the inoculated susceptible cells retained this classification in the third round of screening, as did the five unique clones (1-85, the two tested $P A L$ clones 3-39 and 1-121, 1-124, 1-119, and 7-50) identified as genes up-regulated only in the inoculated resistant cells (Fig. 3). Only clone 5-72 (low temperature and salt-response protein) from the category of clones representing genes tentatively up-regulated in both inoculated cell types (i.e., penetration-specific induction) was included in the third round of screening, and results reconfirmed its classification. The results of all three rounds of differential screening are summarized in Table 1.

\section{Expression of cell death-related genes $L L S 1$ and $H S R 203 J$.}

Globally amplified RT-PCR product from each of the four cowpea epidermal types were probed for the expression of LLS1 (lethal leaf spot 1) (Gray et al. 1997), a gene implicated in the prevention of plant cell death, or HSR203J (Hypersensitivity-related 203J) (Tronchet et al. 2001), a gene commonly used as a marker of the HR. The complete coding region of the cowpea LLS1 (vuLLS1) gene was cloned from cultivar California
Blackeye (CB), and the coding region was found to be 1,635 bp in length, encoding a protein of 545 amino acids and having a molecular mass of $61.38 \mathrm{kDa}$ and a pI of 6.62. Like its homologs in maize and tomato, it contains two structural motifs, a Rieske-type iron-sulphur [2Fe-2S] binding site (Cys-X-His$\mathrm{X}_{16-17}-\mathrm{Cis}-\mathrm{X}_{2}$-His) and a mononuclear iron-binding site (Glu$\mathrm{X}_{3-4}$-Asp- $\mathrm{X}_{2}$-His- $\mathrm{X}_{4-5}$-His), which are present in the $\alpha$-subunit of all aromatic ring-hydroxylating dioxygenases involved in the degradation of phenolic hydrocarbons (Gray et al. 1997). A probe derived from $v u L L S 1$ cDNA indicated that the expression of the vuLLS1 gene was elevated in both infected resistant and susceptible cells before the fungus reached the cell lumen (Fig. 4). Interestingly, the transcripts in these cells were of different sizes, perhaps because of differences in the gene between the two cultivars. The probe derived from Pisum sativum E86 (HSR203J homolog) (Ichinose et al. 2001) revealed expression of a cowpea homolog in all four cell types but with greatly increased expression in the infected resistant cell (Fig. 4).

\section{DISCUSSION}

Despite their obvious usefulness, particularly in plant-fungal interactions in which each fungal individual invades a single plant cell, single-cell extraction techniques have rarely been used to identify transcriptional changes within invaded cells. To our knowledge, the only such published study is that by Matsuda and associates (1997), who performed in situ RTPCR on selected susceptible, powdery mildew-inoculated, epidermal cells that had previously been microinjected with a fixative. However, no sequence data has yet been published. In the current study, we extracted cytoplasm from single, liv-

Table 1. Summary of the nature and differential expression of the clones examined in the three rounds of screening

\begin{tabular}{|c|c|c|c|c|c|c|c|c|}
\hline Gene identity $^{\mathbf{a}}$ & Clone \# & Insert size & Scores & E-value & 1st & 2nd & 3rd & \# Copies \\
\hline Putative $14-3-3$ protein mRNA (NT) & $6-1$ & 268 & 137 & $4 \mathrm{e}^{-30}$ & $\mathrm{DS}^{\mathrm{b}}$ & ND & ND & 1 \\
\hline Putative profilin mRNA (NT) & $1-66$ & 463 & 369 & $1 \mathrm{e}^{-99}$ & DS & ND & ND & 1 \\
\hline Putative auxin repressed protein (EST) & $6-55$ & 611 & 448 & $1 \mathrm{e}^{-123}$ & DS & ND & ND & 1 \\
\hline IAA-inducible gene (best EST) & $6-120$ & 244 & 68 & $3 \mathrm{e}^{-9}$ & DS & ND & - & 2 \\
\hline auxin-responsive protein IAA7 (X) & $5-51$ & 488 & 151 & $6 \mathrm{e}^{-36}$ & DS & ND & - & 2 \\
\hline Chloroplast outer membrane protein(NT) & $4-45$ & 399 & 84 & $8 \mathrm{e}^{-14}$ & DS & ND & - & 2 \\
\hline Putative cellulase (best EST) & $6-54$ & 269 & 240 & $4 e^{-61}$ & DS & DS & - & 1 \\
\hline Expansin-related protein (NT & $6-29$ & 369 & 64 & $6 \mathrm{e}^{-8}$ & DS & DS & ND & 1 \\
\hline Kinase receptor-like protein (EST) & $1-7$ & 257 & 52 & $2 e^{-4}$ & DS & DS & ND & 1 \\
\hline Histone H3-like protein (best EST ) & $1-118$ & 332 & 52 & $2 \mathrm{e}^{-4}$ & DS & ND & - & 1 \\
\hline Nucleotide sugar epimerase (bestEST) & $6-100$ & 281 & 84 & $6 e^{-1}$ & DS & DS & DS & 1 \\
\hline Endotransglycosylase-related protein (EST) & $7-55$ & 278 & 42 & 0.19 & DS & DS & DS & 1 \\
\hline Putative translation initiation factor SUI1 (X) & $5-114$ & 353 & 110 & $5 e^{-24}$ & DS & DS & DS & 1 \\
\hline$\beta$-tubulin (NT) & $6-119$ & 361 & 66 & $2 \mathrm{e}^{-8}$ & DS & DS & DS & 1 \\
\hline$\alpha$-tubulin (NT) & $6-77$ & 322 & 66 & $1 \mathrm{e}^{-8}$ & DS & DS & DS & 1 \\
\hline SI-1 (PR-10) (NT) & $1-85$ & 264 & 500 & $1 \mathrm{e}^{-139}$ & UR & UR & UR & 2 \\
\hline Phenylalanine ammonia-lyase (NT) & $3-29$ & 289 & 192 & $9 \mathrm{e}^{-47}$ & UR & UR & UR & 4 \\
\hline Arginosuccinate synthetase $(\mathrm{X})$ & $1-124$ & 495 & 151 & $8 \mathrm{e}^{-36}$ & UR & UR & UR & 1 \\
\hline Farnesylated protein (Best EST) & $1-119$ & 217 & 107 & $5 e^{-21}$ & UR & UR & UR & 1 \\
\hline Putative synaptobrevin (v-SNARE) (Best EST) & $7-50$ & 419 & 192 & $1 \mathrm{e}^{-46}$ & UR & UR & UR & 1 \\
\hline Hydroxymethyltransferase-related protein(best EST) & $1-110$ & 266 & 50 & $7 e^{-4}$ & UR & ND & - & 1 \\
\hline Unknown & $4-76$ & 397 & $\mathrm{n} / \mathrm{a}$ & $\mathrm{n} / \mathrm{a}$ & PS & PS & - & 6 \\
\hline Unknown & $6-65$ & 165 & $\mathrm{n} / \mathrm{a}$ & $\mathrm{n} / \mathrm{a}$ & PS & PS & - & 3 \\
\hline Low temperature and salt response protein $(\mathrm{X})$ & $5-72$ & 441 & 71 & $1 \mathrm{e}^{-11}$ & PS & PS & PS & 5 \\
\hline Unknown & $1-22$ & 354 & $\mathrm{n} / \mathrm{a}$ & $\mathrm{n} / \mathrm{a}$ & PS & PS & - & 2 \\
\hline Unknown & $6-84$ & 487 & $\mathrm{n} / \mathrm{a}$ & $\mathrm{n} / \mathrm{a}$ & PS & PS & - & 1 \\
\hline Ribsomal protein L-32 (X) & $1-71$ & 451 & 174 & $8 \mathrm{e}^{-43}$ & PS & PS & - & 1 \\
\hline Unknown & $5-14$ & 427 & $\mathrm{n} / \mathrm{a}$ & $\mathrm{n} / \mathrm{a}$ & PS & PS & - & 1 \\
\hline Unknown & 4-101 & 462 & $\mathrm{n} / \mathrm{a}$ & $\mathrm{n} / \mathrm{a}$ & PS & PS & - & 1 \\
\hline Unknown & $1-38$ & 295 & $\mathrm{n} / \mathrm{a}$ & $\mathrm{n} / \mathrm{a}$ & PS & PS & - & 1 \\
\hline RNA-binding protein (EST) & 4-35 & 320 & 276 & $8 \mathrm{e}^{-72}$ & PS & PS & - & 1 \\
\hline+30 clones comprising 18 unique genes & - & - & $\mathrm{n} / \mathrm{a}$ & PS & - & & & \\
\hline
\end{tabular}

\footnotetext{
a Identity based on: $\mathrm{X}=$ blastx, EST = blastn-est, NT = blastn-nr, bestEST = annotated by using the sequence with the highest score from the blastn-est to do another blastn-nr or blastx.

${ }^{\mathrm{b}} \mathrm{ND}=$ no differential expression; PS = apparently up-regulated in inoculated resistant or susceptible cells; DS = apparently down-regulated in inoculated susceptible cells; UR = apparently upregulated in inoculated resistant cells; and $-=$ gene not included.
} 
ing, resistant or susceptible epidermal cells when the cowpea rust fungus was growing through the plant cell wall and before it reached the cell lumen. Previous studies had suggested that changes that occur within the protoplast at this time predict whether the cell exhibits susceptibility (and no cell death) or resistance (hypersensitive cell death) once the fungus enters the cell lumen. Our study, therefore, was designed to examine transcriptional changes that prepared epidermal cells for the subsequent expression of susceptibility or the HR.

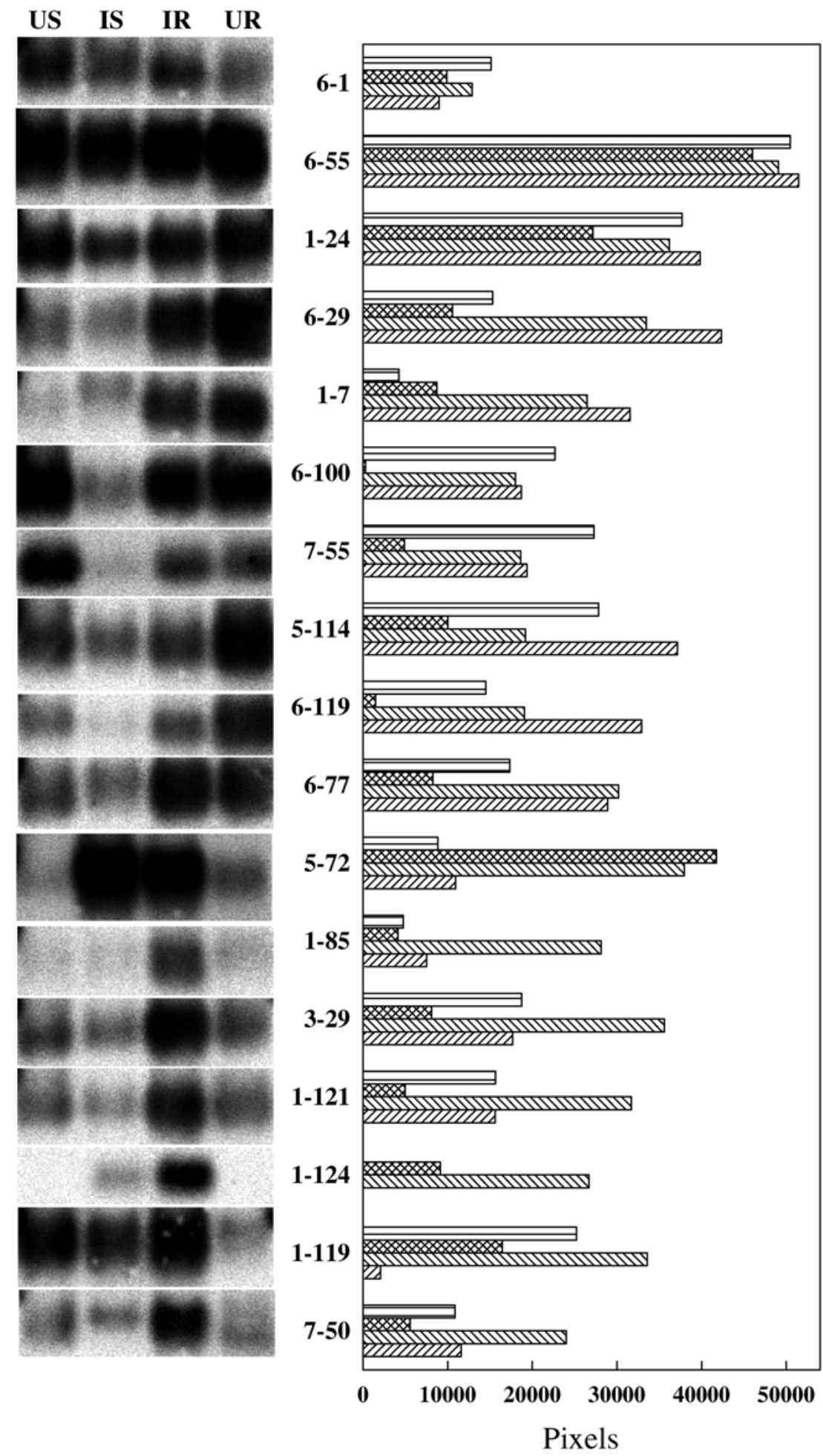

Fig. 3. Third-round screening results. Clones selected on the basis of the second-round screening results were used to probe the uncloned globally amplified reverse transcription-polymerase chain reaction (RT-PCR) product (two rounds of PCR) from each of the four cowpea midvein epidermal cell types. Clone numbers are denoted to the right of the band columns. US $=$ lanes containing RT-PCR product from uninoculated CB cells, IS $=$ lanes containing RT-PCR product from cowpea rust-inoculated CB cells, IR = lanes containing RT-PCR product from cowpea rust-inoculated cv. Dixie Cream (DC) cells, and UR = lanes containing RT-PCR product from uninoculated DC cells. Absolute values for the band intensity, from which the film background value had been subtracted, are shown. $\square=$ US cell RT-PCR product lane, $\mathrm{xxx}=$ IS cell RT-PCR product lane, IIII = IR cell RT-PCR product lane, and IIII = UR cell RT-PCR product lane. Equal loading of lanes was confirmed by ethidium bromide staining of the agarose gel and by probing with clone 6-55, which appeared to represent genes constitutively expressed in the epidermal cells under the described conditions. 
The cowpea rust fungus/cowpea system is unique in that several studies (Heath 1998, Heath et al. 1997) have failed to detect the nonspecific defensive responses commonly observed in other plant-fungal interactions, both compatible and incompatible, when the pathogen starts to breach the cell wall. Experiments suggest that the rust fungus inhibits some of these defenses by preventing the initiating signals from being transduced into the protoplast (Mellersh and Heath 2001) and, in accord with these observations, no typical "defense gene" was found among the genes up-regulated by infection of resistant or susceptible cells, except for a gene related to a stress response gene from Arabidopsis (clone 5-72, Table 1). Nevertheless, the largest category of genes revealed by this study to be differentially expressed while the fungus was still in the cell wall were those up-regulated in both resistant or susceptible inoculated cells, presumably as a nonspecific response to plant wall penetration. As most of them had no matching sequences in the databases, it appears that, even in the absence of detectable defense responses to wall penetration by the rust fungus, fungal growth within the plant wall induces significant changes in gene expression in both resistant and susceptible cells of the host species.

The ultrastructural evidence that translation is down-regulated in susceptible cells as the fungus grows through the epidermal wall (Mould and Heath 1999) was supported in this study by the reduced expression, compared with uninoculated cells, of genes coding for a nucleotide sugar epimerase, a putative endotransglycosylase, a translation initiation factor, and the cytoskeletal proteins $\beta$ - and $\alpha$-tubulin. Interestingly, the down-regulation of the first two genes might relate to previous indications that rust fungi prevent cell wall-related secretory processes in susceptible cells (Heath 1995). Callose deposition, in particular, seems to be inhibited (Škalamera et al. 1997), and although plants possess a large array of nucleotide sugar epimerases (Allard et al. 2001), it is possible that the one cloned here could affect the availability of the callose substrate, D-glucose. However, since the recently identified haustorial hexose transporter of the faba bean rust fungus appears to have a substrate specificity for D-glucose and D-fructose (Voegele et al. 2001), down-regulating an epimerase gene could be part of the establishment of a compatible interaction whereby the host cell is prevented from diverting these two sugars into others less useful to the fungus.

The reduced expression of tubulin genes in infected susceptible but not resistant (see below) cells correlates with the more rapid, localized reduction in microtubules in the former at the

\section{US IS IR UR}

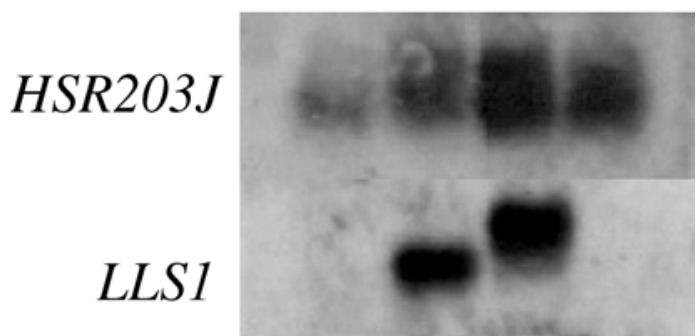

Fig. 4. Expression pattern of cell death marker genes LLS1 and HSR203J. Cowpea LLS1 and pea E86 (HSR203J homolog) were used to probe the globally amplified reverse transcription-polymerase chain reaction (RTPCR) product (two rounds of PCR) from each of the four cowpea midvein epidermal cell types. US = lanes containing RT-PCR product from uninoculated CB cells, IS = lanes containing RT-PCR product from cowpea rust-inoculated CB cells, IR = lanes containing RT-PCR product from cowpea rust-inoculated cv. Dixie Cream (DC) cells, and UR = lanes containing RT-PCR product from uninoculated DC cells. site of fungal penetration (Mould and Heath 1999). Interestingly, degradation of $\beta 1$-tubulin mRNA has been related to an increase in cytosolic $\mathrm{Ca}^{2+}$ levels in elicitor-treated soybean cells (Ebel et al. 2001), whereas in the present system, a significant increase in cytosolic $\mathrm{Ca}^{2+}$ levels only occurs in resistant cells (Xu and Heath 1998) in which no early reduction in the tubulin gene expression was detected. It should be noted that this study was not designed to identify genes that were specifically up-regulated in infected susceptible cells, although the globally amplified cDNA is available to construct a similarly screenable library from these cells.

Although it has been recognized for some time that the HR requires gene transcription and translation (Dixon et al. 1994), the nature of the required gene expression is unknown. Thus, the primary aim of this study was to identify genes that might be involved in preparing the resistant cell for the HR. Of the five genes found to be specifically up-regulated in resistant cells as the fungus grew through their cell walls, two are genes potentially involved in defense responses and three potentially involved in intracellular signaling or trafficking. The first subgroup includes $P R-10$ and $P A L$, while the second subgroup includes the clones for arginosuccinate synthetase, an as yet to be identified farnesylated protein, and a putative v-SNARE protein that could be involved in vesicle fusion (Blatt et al. 1999). Interestingly, this suite of genes does not show any clear resemblance to those reported from five studies published to date on genes up-regulated at an early stage of a resistance-genemediated HR in pathosystems other than rust fungi (Birch et al. 1999; Durrant et al. 2000; Karrer et al. 1998; Lambert et al. 1999; Ludwig and Tenhaken 1998, 2001; Yoda et al. 2002), and a possible reason for this may be the different pathogens involved and the fact that most other studies used tissue or cultured cells containing a mixture of dying cells and cells that could have been defensively responding to their dying neighbors. However, $P A L$ transcripts have been shown to rapidly and preferentially accumulate in incompatible and inappropriate combinations of oat tissue and the dikaryotic stage of the rust fungus, Puccinia graminis, prior to the autofluorescence of dying cells (Lin et al. 1998).

The significance of the up-regulated genes to the initiation of the HR in the rust-resistant cowpea cells remains to be elucidated. However, three of these genes merit particular mention. Arginosuccinate synthetase is involved in the biosynthesis of arginine, which is a substrate for a yet-to-be-identified plant nitric oxide (NO) synthetase (Durner and Klessig 1999). NO production appears to be crucial in the early stage of the HR, both in TMV-infected NN tobacco plants (Durner et al. 1998) and in bacterium-inoculated soybean cell cultures and A. thaliana plants (Delledonne et al. 1998). As well, Delledonne and associates (2001) have demonstrated that, in the bacterium-inoculated soybean culture cells, the maintenance of a balanced production of $\mathrm{NO}$ and $\mathrm{H}_{2} \mathrm{O}_{2}$ is a determining factor in whether the cells undergo a HR. However, as there is no detectable $\mathrm{H}_{2} \mathrm{O}_{2}$ generation in the cowpea/cowpea rust fungus pathosystem until after the cells begin to die (Heath 1998), an alternative role for an increased arginine pool would be the synthesis of di- or polyamines. Levels of putrescine specifically increase within 5 $\mathrm{h}$ of inoculation of resistant NN tobacco plants with TMV, leading to the suggestion that it could have a role in signaling pathways leading to the HR (Rabiti et al. 1998).

The second gene of particular interest is $P A L$. Four of the original 10 clones found to be up-regulated in resistant inoculated cells were of $P A L$, suggesting that PAL mRNAs may comprise a substantial proportion of the mRNA pool related to genes specifically expressed in resistant cells as they prepare for the HR. Presumably, cowpea resembles other dicotyledonous plants, such as the related Phaseolus vulgaris 
(Cramer et al. 1989), in containing a family of PAL genes. As reviewed by Dixon and Paiva (1995), PAL is the first enzyme in the phenylpropanoid pathway, resulting in the production of a variety of phenolic compounds, such as the cowpea antimicrobial phytoalexins kievitone and phaseollidin (LatundeDada and Lucas 2001), and the intermediary compounds of lignin. Given the lack of wall autofluorescence during fungal penetration in the cowpea/cowpea rust pathosystem and the initially normal growth of the fungus after it enters the plant cell lumen (Heath et al. 1997), it seems unlikely that the $P A L$ gene is involved in producing defensive phenolics as part of a nonspecific response to the penetration process. It seems equally unlikely that it is involved in the eventual accumulation of autofluorescent phenolic compounds within the cell that occurs after the death process is completed and which seems to involve the activity of surrounding living cells (Škalamera and Heath 1998). The alternative is that this gene is specifically involved in the initiation of the resistancegene-controlled HR, and an intriguing possibility is that the gene is involved in the production of salicylic acid (SA) (Rasmussen and Dixon 1999). Given the considerable literature that demonstrates the importance of SA in the HR (Mur et al. 2000), a tenable hypothesis is that the role of PAL in the infected rust-resistant cowpea cells is to accelerate the death process via SA production.

The third gene of particular interest is $P R-10$, particularly in the light of recent reports that overexpression of a $P R-10$ gene from Catharanthus roseus increases endogenous cytokinin content in transgenic tobacco plants (Elbez et al. 2002) and that cytokinins can be inducers of a plant-programmed cell death involving the cleavage of DNA into oligonucleosomal fragments (Carimi et al. 2003), a phenomenon also seen in the cowpea rust-induced HR (Ryerson and Heath 1996). In detached leaves, the application of exogenous kinetin is essential for the expression of the HR in the cowpea/cowpea rust pathosystem (Chen and Heath 1991), suggesting that the increased expression of $P R-10$ may play a role in the HR that involves changes in cellular cytokinin levels.

Although only a limited number of differentially expressed genes were detected by screening with probes from the resistant cell library, the availability of globally amplified cDNAs from both resistant and susceptible, inoculated and uninoculated, cells allows screening for the expression of known genes that might be involved in the plant-pathogen interaction. Therefore, we investigated the expression of the cowpea homolog of the LLS1 gene of maize, which in maize codes for a chloroplast-localized protein suggested to protect the chloroplast following biotic or abiotic stress and which leads to cell death when it is absent (Gray et al. 2002). This gene was up-regulated in both resistant and susceptible cells, suggesting that it may not play a direct role in the HR but is induced in response to wall penetration. In contrast, resistant cells showed the specific up-regulation of a gene transcript related to a pea homolog of HSR203J, a tobacco gene coding for a serine hydrolase that has been widely accepted as a marker for the HR, although more recently suggested to be involved in the suppression of hypersensitive cell death (Tronchet et al. 2001). Whether the expression of this gene is intimately involved in the HR or is a consequence of the events set in motion by the $\mathrm{HR}$ induction process remains to be determined. Interestingly, homologs of LLS1 and PAL but not PR-10 or HSR203J appear in the sequences obtained from GenBank for a cDNA library from Zinnia cells undergoing a programmed cell death during differentiation into tracheary elements (Demura et al. 2002), suggesting that the expression of $P R-10$ and HSR203J genes may be more specific to the HR than to developmental programmed cell death in plants.
In conclusion, therefore, this study has demonstrated that changes in gene expression occur in resistant and susceptible epidermal cells prior to the rust fungus reaching the cell lumen and that some genes are specifically down-regulated in susceptible cells, while others are specifically up-regulated in resistant cells. Given the dependence of the HR in this pathosystem on transcription and translation (Heath et al. 1997), it seems likely that these up-regulated genes are intimately involved in preparing the cell for the hypersensitive cell death that will occur after the fungus has entered the cell.

\section{MATERIALS AND METHODS}

\section{Plant and fungal material.}

Ten-day-old cowpea (Vigna unguiculata [L.] Walp.) plants were grown as previously described (Chen and Heath 1991). Basidiospores of race 1 of the cowpea rust fungus (Uromyces vignae Barclay) were prepared from teliospores, and plants of the rust-susceptible (CB) or rust-resistant (Dixie Cream) cultivars were inoculated as described by Mould and Heath (1999).

\section{Selection and extraction of epidermal cells.}

All equipment was surface-sterilized with $95 \%$ ethanol. The internal surfaces of the pressure hose and body of the manually operated screw-drive pressure injector/extractor were sterilized with $3 \% \mathrm{H}_{2} \mathrm{O}_{2}(2 \mathrm{~h})$ and thoroughly rinsed with diethylpyrocarbonate-treated Milli-Q water. Extractions were performed in a room with noncirculating ambient air and separate from that used for either RT-PCR or other downstream nucleic acid manipulations.

Individual micropipettes per cell were pulled from sterilized borosilicate electrode filament glass (ID $=0.58 \mathrm{~mm}, \mathrm{OD}=1.0$ $\mathrm{mm}$ ) (Friedrich \& Dimmock, Milville, NJ, U.S.A.) using a micropipette puller (model PP-63, Narishige Scientific Instrument Lab, Tokyo). Pulled ends were cut to an approximate inner diameter opening of $2.5 \mu \mathrm{m}$, using the flat side of a heatsterilized scalpel blade. Each micropipette was lubricated by back-filling with hexamethyldisiloxane (Sigma Chemical Co., St. Louis), was inserted into the pressure extractor (provided by R. R. Lew, York University, Toronto, Ontario, Canada), and was mounted on a manually operated Leitz (Wetzlar, Germany) micromanipulator.

Uninoculated and rust-inoculated plants were incubated in the humidity chamber for 7 to $9 \mathrm{~h}$, after which individual primary leaves were removed at the petiole and, after gentle removal of the inoculum-bearing agar strip from the leaf surface of the rust-inoculated plants, the abaxial portion of the midvein was removed with a double-edged razor blade. Prepared leaves were mounted in sterile double-distilled water on a coverslip $(22 \times 40 \mathrm{~mm})$ mounted over an open slot (slightly less than 22 $\times 40 \mathrm{~mm}$ ) cut into a $25 \times 75 \mathrm{~mm}$ polystyrene microscope slide. Double-sided sticky tape secured both the coverslip and the leaf in place over the slot. Observations were made with a Reichert (Leica, Germany) light microscope equipped with differential interference contrast optics. For rust-inoculated plants, infection sites corresponding to the early stage of epidermal wall penetration were located based on the positioning of the plant cell nucleus directly beneath the fungal penetration point (Heath et al. 1997; Mould and Heath 1999). Usually, only two infection sites corresponding to this stage could be located per leaf. For uninoculated plants, four midvein epidermal cells per leaf were randomly selected for extraction. Leaves were discarded within 15 min after excision from the plant.

Once identified, the micropipette was positioned over the particular epidermal cell at an approximately $45^{\circ}$ angle and was lowered so that the tip just contacted the cell cuticle. Gentle pressure was applied to the micromanipulator joystick to 
puncture the cuticle and cell wall, and the cell contents were aspirated into the micropipette with slight negative pressure applied from the extractor. On withdrawal of the micropipette from the cell, the cytoplasm was ejected from the micropipette into $5.0 \mu \mathrm{l}$ of TriReagent (Molecular Research Center, Inc., Cincinnati, OH, U.S.A.) in a $0.5-\mathrm{ml}$ microfuge tube, and was immediately plunge-frozen in liquid $\mathrm{N}_{2}$ and stored at $-80^{\circ} \mathrm{C}$. Cells were discarded if the micropipette tip contacted the fungus or penetrated beyond the given epidermal cell. The total number of extracted cells were 121 (resistant uninoculated), 92 (resistant inoculated), 115 (susceptible uninoculated), and 97 (susceptible inoculated).

For scanning electron microscope (SEM) examination, tissue pieces encompassing extracted cells were stored in $75 \%$ ethanol $\left(4^{\circ} \mathrm{C}\right.$, minimum $\left.48 \mathrm{~h}\right)$, were further dehydrated in $100 \%$ ethanol (two $30-\mathrm{min} 4^{\circ} \mathrm{C}$ washes), were critical point dried using an Autosamdri-814 (Tousimis Research Corp., Rockville, MD, U.S.A.), were mounted on aluminum stubs, and were gold-coated (two coats, $30 \mathrm{~s} /$ coat) using a Cressington sputter coater (Cressington Scientific Instruments, Cranberry Township, PA, U.S.A.). Specimens were examined with a Hitachi S2500 SEM (Hitachi, Ltd., Tokyo) operating at $15 \mathrm{kV}$. Images were captured on Kodak Tri-X pan film or with a Hitachi SuperScan Elite 641 digital image system.

\section{RNA isolation, cDNA synthesis, and PCR amplification.}

Unless otherwise noted, all molecular biological reagents, including ultrapure water, were from Life Technologies, Inc. (Rockville, MD, U.S.A.). RT and PCR primers were synthesized at the, Hospital for Sick Children DNA Synthesis Facility (Toronto, Ontario). For total RNA isolation, microcentrifuge tubes for the particular extracted cell type (e.g., inoculated rust-resistant) were thawed on ice, and the contents (extracted cytoplasm plus TriReagent) were amalgamated into a single 0.5-ml tube. The RNA was isolated following the TriReagent protocol. A second chloroform extraction was included after the initial aqueous and organic phase separation step. For RNA precipitation $\left(4^{\circ} \mathrm{C}, 60 \mathrm{~min}\right.$ minimum $), 20 \mu \mathrm{g}$ of ultrapure glycogen were thoroughly mixed into the final aqueous phase (approximately $200 \mu \mathrm{l}$ ), prior to adding $200 \mu \mathrm{l}$ of isopropanol. Each RNA pellet was resuspended in $4 \mu \mathrm{l}$ of first-strand cDNA synthesis buffer (Brady and Iscove 1993), was transferred to a 200- $\mu$ l thin-walled PCR tube, and within $30 \mathrm{~min}$, was subjected to the RT-PCR procedure.

RT, 3' polyadenylation, and global amplification of the first strand cDNA pools were performed as previously described (Brady and Iscove 1993; Iscove et al. 2002). To globally amplify the poly(A) cDNAs generated from the inoculated or control rust-resistant or -susceptible cells, triplicate 20.0- $\mu$ l PCR reactions per cell type were performed. For each reaction, a $4.0-\mu \mathrm{l}$ aliquot of the given cell type poly(A)-tailed cDNA pool was added to $14.8 \mu \mathrm{l}$ of $1 \times$ PCR mix (Brady and Iscove 1993), was overlaid with $30.0 \mu \mathrm{l}$ of mineral oil, and was heated to $94^{\circ} \mathrm{C}$, at which time, $0.2 \mu \mathrm{l}$ of the poly-T primer $\left(10.0 \mathrm{pmol}^{\mathrm{l}} \mathrm{l}^{-1}\right)$, followed by $1.0 \mu \mathrm{l}$ of a 50:1 mix of Taq/Pfu (Stratagene, La Jolla, CA, U.S.A.) DNA polymerase were added. Cycling conditions were: one cycle of $94^{\circ} \mathrm{C}$ for $15 \mathrm{~s}, 50^{\circ} \mathrm{C}$ for $2 \mathrm{~min}, 72^{\circ} \mathrm{C}$ for 2 min, and then 30 cycles of $94^{\circ} \mathrm{C}$ for $15 \mathrm{~s}, 60^{\circ} \mathrm{C}$ for $30 \mathrm{~s}, 72^{\circ} \mathrm{C}$ for $2 \mathrm{~min}$. One microliter of a fivefold dilution of the first-round PCR product was used as template for second-round $20.0-\mu \mathrm{l}$ PCR reamplifications $\left(35\right.$ cycles of $94^{\circ} \mathrm{C}$ for $15 \mathrm{~s}, 60^{\circ} \mathrm{C}$ for $30 \mathrm{~s}$, $72^{\circ} \mathrm{C}$ for $2 \mathrm{~min}$ ), and $20 \%$ of this PCR product was analyzed by agarose $(1.8 \%)$ gel electrophoresis. No template negative controls were included for the RT-PCR and PCR reactions. Positive RT-PCR and PCR control template consisted of RNA and poly(A) cDNA, respectively, equivalent to that isolated or generated from a single human hemopoietic cell.
Globally amplified cDNA from the inoculated rust-resistant cells was also amplified through a third round of PCR using six 50.0- $\mu \mathrm{l}$ replicate reactions. Template was $1.0 \mu \mathrm{l}$ of a $1: 100$ dilution of the second-round PCR product. Cycling conditions and agarose gel electrophoresis were as described for the second-round of PCR. PCR product from two of the six tubes was combined (i.e., $90.0 \mu \mathrm{l}$ total), was spin column purified (Qiagen Inc., Mississauga, Ontario, Canada), and was utilized for construction of a plasmid library.

\section{Library construction.}

A 1.5- $\mu$ l aliquot of the purified, third-round PCR product from the inoculated rust-resistant cells was EcoRI-digested (20 units, $150 \mathrm{~min}, 37^{\circ} \mathrm{C}$, total volume of $25.0 \mu \mathrm{l}$ ) and thereafter electrophoresed in one lane of a $1.0 \%$ low-melting agarose (Bioshop Ltd., Toronto, Ontario, Canada) gel for $20 \mathrm{~min}$. The 11-bp end fragments migrated away from the DNA "band" (representing the desired EST pool), which was excised from the gel and eluted from the agarose using a Qiagen gel extraction kit. To ensure proper DNA elution, $10.0 \mu \mathrm{l}$ of 3.0 M NaAc, $\mathrm{pH}$ 5.2, was added to the melted agarose, as recommended by the kit manufacturer. This gel-purified PCR product $(20 \mathrm{ng})$ was ligated ( $5 \mathrm{~min}$ at room temperature, and then, $30 \mathrm{~min}$ at $16^{\circ} \mathrm{C}$ ) into an EcoRI-digested pUC18 vector (100 ng) previously dephosphorylated with bacterial alkaline phosphatase (Ready-To-Go vector, Amersham Pharmacia Biotech, Baie d'Urfe, Quebec). A vector/insert molar ratio of 1:1 was selected, based on an estimated average insert fragment length of 300 bp. XL-10 Gold (Stratagene). Escherichia coli were transformed $\left(30 \mathrm{~s}\right.$ at $\left.42^{\circ} \mathrm{C}\right)$ using $2.0 \mu \mathrm{l}$ of the ligation mixture, and the entire 200.0- $\mu$ l transformation mixture was plated out in $20.0-\mu \mathrm{l}$ aliquots on Luria Bertani ampicillin $(50.0 \mu \mathrm{g} / \mathrm{ml})$ plates supplemented with $10.0 \mu \mathrm{l}$ of $100.0 \mathrm{mM}$ IPTG and $50.0 \mu \mathrm{l}$ of $40.0 \mathrm{mg} / \mathrm{ml} \mathrm{X-gal}$. Plasmid insert DNA presence was confirmed by colony PCR using primers flanking the vector insert site (5'-GCAGGTCGACTCTAGAGGATCCCCGGGTAC-3', 5'-CAATTTCACACAGGAAACAGCTATGACCATG-3'). Сycling conditions were $94^{\circ} \mathrm{C}$ for $4 \mathrm{~min}$, followed by 30 cycles of $94^{\circ} \mathrm{C}$ for $30 \mathrm{~s}, 55^{\circ} \mathrm{C}$ for $45 \mathrm{~s}$, and $72^{\circ} \mathrm{C}$ for $3 \mathrm{~min}$. Each colony PCR product (20\%) was electrophoresed on a $1 \%$ agarose gel, and colonies with confirmed insert-bearing plasmid DNA were replated (four replicate plates) in arrays of 125 different colonies per plate.

\section{Library screening.}

To identify potential differentially regulated plant genes during the very early stage of fungal penetration, the EST library generated from the microcapillary-extracted inoculated rustresistant cowpea cells was initially screened en masse using a colony hybridization technique. Replicate nylon $(0.45-\mu \mathrm{M}$ pore Nytran SuperCharge [Schleicher \& Schuell, Keene, NH, U.S.A.]) membranes bearing insert-containing plasmid DNA from the arrayed colonies were prepared using a one-step microwave denaturation and fixation procedure (Buluwela et al. 1989). Colony arrays were absorbed onto the membranes by placing the membrane (presoaked in the $2 \times \mathrm{SSC}(1 \times \mathrm{SSC}$ is $0.15 \mathrm{M} \mathrm{NaCl}$ plus $0.015 \mathrm{M}$ sodium citrate), 5\% SDS, pH 7.0, lysis buffer) on the agar for $60 \mathrm{~s}$. Colonies were lysed, and the DNA was denatured and fixed to the membrane by microwaving each membrane at maximum power for three, 1-min pulses. Membranes were then concomitantly probed with labeled, globally amplified cDNAs generated from extracted midvein epidermal cells of uninoculated resistant or inoculated resistant and susceptible plants. Probes were prepared by nonradioactively labeling (fluorescein- $\mathrm{N}^{6}$-dATP) $250.0 \mathrm{ng}$ (determined by absorbance at $260 \mathrm{~nm}$ wavelength) of globally amplified cDNAs generated from the given cell type using a Renaissance 
Random Primer Fluorescein Labeling Kit (NEN Life Sciences Corp., Boston). Labeling reactions were overnight at room temperature.

For hybridizations, membranes were prewashed twice in 50 $\mathrm{ml}$ of $2.0 \times \mathrm{SSC}\left(10 \mathrm{~min}\right.$ per wash), were prehybridized at $62^{\circ} \mathrm{C}$ for $70 \mathrm{~min}$ with $1.0 \mathrm{ml} \mathrm{cm}{ }^{-2}$ of prehybridization solution $(2.0 \times$ SSC, $0.5 \%$ blocking reagent [supplied with the kit], $5 \%$ dextran sulphate [MW > 500,000], 0.1\% SDS, $50 \mu \mathrm{g} \mathrm{ml}^{-1}$ salmon sperm DNA), and was hybridized overnight at $62.0^{\circ} \mathrm{C}$, using a probe concentration of $20.0 \mathrm{ng}$ per liter of hybridization solution $\left(0.1 \mathrm{ml} \mathrm{cm}^{-2}\right.$ of membrane). Stringency washes $(2.0 \times \mathrm{SSC}$, $1 \%$ SDS, followed by $0.2 \times$ SSC, $0.1 \%$ SDS) were for $30 \mathrm{~min}$ at $62.0^{\circ} \mathrm{C}$. Detection buffer washes were as noted in the kit manual, except that a minimum of two, 5-min washes in buffer $\# 1$ ( $0.15 \mathrm{M} \mathrm{NaCl}, 0.1 \mathrm{M}$ Tris $\mathrm{HCl}, \mathrm{pH} 7.5)$ were performed prior to the blocking step to remove all traces of SDS. Further blocking (buffer \#1 plus $0.5 \%$ wt/vol blocking agent), along with the antifluorescein antibody-alkaline phosphatase conjugate (1:1000 dilution) incubation steps were for $70 \mathrm{~min}$. Unbound antibody was removed with four, 5-min washes in buffer \#1, followed by two, 5-min washes in buffer \#3 $(0.1 \mathrm{M} \mathrm{NaCl}$, $0.1 \mathrm{M}$ Tris. $\mathrm{HCl}, \mathrm{pH} 9.5)$, using a minimum of $10 \mathrm{ml}$ of buffer solution per square $\mathrm{cm}$ of membrane per wash. Following incubation with the CDP-Star chemiluminiscent detection reagent ( $5 \mathrm{~min}, 0.02 \mathrm{ml} \mathrm{cm}^{-2}$ of membrane), membranes were aligned in a film cassette equipped with a BioMax MS intensifying screen. Single sheets of BioMax MS X-ray film, concomitantly covering all three membranes, were exposed for 40 to $50 \mathrm{~min}$ at room temperature.

Differences in the hybridization signal intensity patterns between the sets of three replicate membranes were determined by eye. Genes tentatively up-regulated only in the inoculated rust-resistant cells were identified by colonies that showed a stronger signal on the membrane probed with labeled product generated from the inoculated rust-resistant cells relative to the membranes probed with labeled product from either the uninoculated resistant or inoculated susceptible cells. Genes tentatively up-regulated in both infected resistant and susceptible cells (i.e., penetration specific) were identified by colonies that showed a stronger signal when probed with the labeled product from either of the inoculated cell types. Genes tentatively down-regulated in infected susceptible cells were represented by colonies that showed a comparatively weak signal when probed with the labeled product from the inoculated rustsusceptible cells. Plasmid insert DNA from clones representing tentative differentially expressed genes was sequenced at the Core Molecular Biology Facility, York University (Toronto). Sequence comparisons were performed using BLASTN and BLASTX (Altschul et al. 1997), and the sequences were aligned using the CLUSTALW (1.81) sequence alignment program.

Clones selected as representing tentative differentially expressed genes were further screened utilizing slot-blot analysis, the probes being those used for the colony screening procedure. Per clone, both 60 and $6.0 \mathrm{ng}$ of insert-bearing plasmid DNA were denatured with $750.0 \mu \mathrm{l}$ of $100 \mathrm{mM} \mathrm{NaOH}(5 \mathrm{~min}$ at $37^{\circ} \mathrm{C}$ ) and were neutralized with an equivolume $12 \times \mathrm{SSC}$ per tube. For each membrane, $500.0 \mu \mathrm{l}$ of each denatured DNA sample (equivalent to 10.0 or $1.0 \mathrm{ng}$ ) were transferred to the nylon membrane in $6 \times$ SSC, using a Schleicher \& Schuell Minifold-II slot-blot apparatus. Membranes were briefly airdried, and the DNA was cross linked (two exposures, autocross link setting) using a UV Stratalinker 2400 (Stratagene), followed by baking at $85^{\circ} \mathrm{C}$ for $1 \mathrm{~h}$. Hybridization, washing, antibody conjugate incubation, and detection were as described above. Film exposure times ranged between 2 to 5 min. Developed films were scanned using an Agfa Duoscan T1200 scan- ner (Agfa N.V., Mortsel, Belgium) and the band intensity value per slot was determined using the line scan function of the Northern Eclipse image analysis software (Empix Imaging, Mississauga, Ontario).

As a final, tertiary confirmation, the globally amplified (two rounds of PCR) cDNAs generated from the uninoculated and inoculated rust-resistant and -susceptible cells were probed with $250 \mathrm{ng}$ of insert-bearing plasmid DNA from the selected individual clones. Four replicate sets of lanes were loaded with $5.0 \mu \mathrm{g}$ of PCR product per cell type per lane in a $1.8 \%$ agarose gel. Gels were run for $60 \mathrm{~min}$ at 120 volts. DNA was transferred to nylon membranes according to standard protocol (Sambrook et al. 1989) and affixed as described above, after which the membrane was cut into four separate blots (i.e., each blot bearing four lanes, one lane of each blot representing one of the four different cell types) and each blot was probed with a different, labeled clone. Membrane washing, prehybridization, hybridization, stringency washes, probe detection, and band intensity value determinations were as described above. All membranes per hybridization experiment were exposed ( $30 \mathrm{~s}$ to 2 $\mathrm{min}$ ) on the same piece of film. Longer exposure times (e.g., 5 min) indicated that exposure for 2 min was below the film saturation level. Membranes were stripped for reprobing by performing two, 15 -min washes in $0.1 \times \mathrm{SSC}, 0.5 \% \mathrm{SDS}$ at $90^{\circ} \mathrm{C}$, followed by five washes in $2 \times$ SSC to remove any SDS. Equal loading was confirmed by EtBr staining of the agarose gels and by probing with a clone for a midvein epidermal cell constitutively expressed gene encoding an auxin-repressed protein.

Clones listed in Table 1 have been assigned GenBank accession numbers CB68060 to CB968090, inclusively.

\section{Cloning of cowpea $L L S 1$ homolog.}

The SMART RACE cDNA Amplification Kit (Clontech Laboratories, Windsor, Ontario) was used to clone cowpea LLS1 homolog (GenBank accession number AY257179). Leaves of 9-day-old CB cowpea plants were heavily inoculated with basidiospores. The total RNA was extracted with TriReagent from leaves harvested 5 days postinoculation, and the templates cDNA for 3' RACE and 5' RACE and PCR were prepared according to the manufacture's manual (Clontech Laboratories) with SuperScript II reverse transcriptase (Gibco BRL, Life Technologies, Burlington, Ontario, Canada). Degenerated primer P3RACE 5'-CCNGTNGTNYTNCCNGAYYTN CC-3' $(\mathrm{N}=\mathrm{A} / \mathrm{T} / \mathrm{G} / \mathrm{C}, \mathrm{Y}=\mathrm{C} / \mathrm{T})$ was used as a gene-specific primer for $3^{\prime}$ RACE, and PLLS15RACE 5'-CTCACGTTTGGATAAAACTGTTGATGGC-3' was used as the gene-specific primer for $5^{\prime} \mathrm{RACE}$. The amplified DNA fragments were cloned in PCR2.1 vector following instructions of the TA Cloning Kit (Invitrogen Canada, Burlington, Ontario, Canada) and were sequenced at the Core Molecular Biology Facility, York University. The coding region of cowpea $L L S 1$ was amplified with PCR using primers PLLS15' (5'-ATGGCACTCCCGCACTCCATCTC-3') and PLLS13' (5'-TTCGATTTCTGCATGCACGTAATCG-3') and was cloned into PCR2.1 vector and then sequenced. All the PCR reactions were done using the following conditions: template cDNA 5.0 $\mu$ l, 10× PCR buffer (Clontech Laboratories), 5.0 $\mu \mathrm{l}, 5.0 \mathrm{mM}$ dNTP $2.0 \mu \mathrm{l}, 10.0 \mu \mathrm{M}$ primers each $2.5 \mu \mathrm{l}$, DNA polymerase $1.0 \mu \mathrm{l}$, adding $\mathrm{H}_{2} \mathrm{O}$ to $50 \mu \mathrm{l}$, cycling at $95^{\circ} \mathrm{C}$ for 5 min followed by 30 cycles of $95^{\circ} \mathrm{C}$ for $45 \mathrm{~s}, 65^{\circ} \mathrm{C}$ for 1 $\mathrm{min}$, and $72^{\circ} \mathrm{C}$ for $3 \mathrm{~min}$, followed by $72^{\circ} \mathrm{C}$ for $20 \mathrm{~min}$.

\section{Expression of $L L S 1$ and $H S R 203 J$.}

To investigate the expression of LLS1 and HSR203J genes during the fungal infection, the globally amplified cDNA of inoculated and uninoculated susceptible and resistant cells were separated, blotted, and hybridized with probes derived from 
CB cowpea LLS1 cDNA and E86 cDNA (pea HSR203J homolog, a gift from Y. Ichinose) as described above.

\section{ACKNOWLEDGMENTS}

This research was supported by a grant from the Natural Sciences and Engineering Council of Canada (M. C. Heath) and from the National Cancer Institute of Canada (N. N. Iscove). M. J. R. Mould was a recipient of an Ontario Graduate Scholarship. We wish to thank E. Blumwald (University of Toronto and University of California-Davis) for the generous use of his equipment and Y. Ichinose (Okayama University) for the gift of the E86 clone containing the pea HSR203J homolog (AB026296)).

\section{LITERATURE CITED}

Allard, S. T. M., Giraud, M.-F., and Naismith, J. H. 2001. Epimerases: Structure, function and mechanism. Cell. Mol. Life Sci. 58:1650-1665.

Altschul, S. F., Madden, T. L., Schaffer, A. A., Zhang, J. H., Zhang, Z., Miller, W., and Lipman, D. J. 1997. Gapped BLAST and PSI-BLAST: A new generation of protein database search programs. Nucleic Acids Res. 25:3389-3402.

Birch, P. R. J., Avrova, A. O., Duncan, J. M. Lyon, G. D., and Toth, R. L. 1999. Isolation of potato genes that are induced during an early stage of the hypersensitive response to Phytophthora infestans. Mol. PlantMicrobe Interact. 12:356-361.

Blatt, M. R., Leyman, B., and Geelen, D. 1999. Molecular events of vesicle trafficking and control by SNARE proteins in plants. New Phytol. 144:389-418.

Brady, G., and Iscove, N. N. 1993. Construction of cDNA libraries from single cells. Meth. Enzymol. 225:611-623.

Buluwela, L., Forster, A., Boehem, T., and Rabbitts, T. H. 1989. A rapid procedure for colony screening using nylon filters. Nucleic Acids Res. 17:452.

Carimi, F., Zottini, M., Formentin, E., Terzi, M., and Lo Schiavo, F. 2003. Cytokinins: New apoptotic inducers in plants. Planta 216:413-421.

Chen, C. Y., and Heath, M. C. 1991. Cytological studies of the hypersensitive cell death of cowpea epidermal cells induced by basidiosporederived infection by the cowpea rust fungus. Can. J. Bot. 69:11991206.

Cramer, C. L., Edwards, K., Dron, M., Liang, X., Dildine, S. L., Bolwell, G. P., Dixon, R. A., Lamb, C. J., and Schuch, W. 1989. Phenylalanine ammonia-lyase gene organization and structure. Plant Mol. Biol. 12:367-383

Demura, T., Tashiro, G., Horiguchi, G., Kishimoto, N., Kubo, M., Matsuoka, N., Minami, A., Nagata-Hiwatashi, M., Nakamura, K., Okamura, Y., Sassa, N., Suzuki, S., Yazaki, J., Kikuchi, S., Fukuda, H. 2002. Visualization by comprehensive microarray analysis of gene expression programs during transdifferentiation of mesophyll cells into xylem cells. Proc. Natl. Acad. Sci. U.S.A. 99:1579415799.

Delledonne, M. Xia, Y., Dixon, R. A., and Lamb, C. 1998. Nitric oxide functions as a signal in plant disease resistance. Nature 394:585588 .

Delledonne, M., Zeier, J., Marocco, A., and Lamb, C. 2001. Signal interactions between nitric oxide and reactive oxygen intermediates in the plant hypersensitive disease resistance response. Proc. Natl. Acad. Sci. U.S.A. 98:13454-13459.

Dixon, R. A., and Paiva, N. L. 1995. Stress-induced phenylpropanoid metabolism. Plant Cell 7:1085-1097.

Dixon, R. A., Harrison, M. J., and Lamb, C. J. 1994. Early events in the activation of plant defense responses. Annu. Rev. Phytopathol. 32:479. 501

Durner, J., and Klessig, D. F. 1999. Nitric oxide as a signal in plants. Curr. Opin. Plant Biol. 2:369-374.

Durner, J., Wendehenne, D., and Klessig, D. F. 1998. Defense gene induction in tobacco by nitric oxide, cyclic GMP, and cyclic ADPribose. Proc. Natl. Acad. Sci. U.S.A. 95:10328-10333.

Durrant, W. E., Rowland, O., Piedras, P. Hammond-Kosack, K. E., and Jones, J. D. G. 2000. cDNA-AFLP reveals a striking overlap in racespecific resistance and wound response gene expression profiles. Plant Cell 12:963-977.

Ebel, C., Gómez, L. G, Schmit, A.-C., Neuhaus-Url, G., and Boller, T. 2001. Differential mRNA degradation of two $\beta$-tubulin isoforms correlates with cytosolic $\mathrm{Ca}^{2+}$ changes in glucan-elicited soybean cells. Plant Phys. 126:87-96.

Elbez, M., Kevers, C., Hamdi, S., Rideau, M., and Petit-Paly, G. 2002. The plant pathogenesis-related PR-10 proteins. Acta Botanica Gallica 149:415-444.
Goodman, R. N., and Novacky, A. J. 1994. The Hypersensitive Reaction in Plants to Pathogens. American Phytopathological Society, St. Paul, MN, U.S.A.

Gray, J., Close, P. S., and Johal, G. 1997. A novel suppressor of cell death in plants encoded by the $L l s 1$ gene of maize. Cell 89:25-31.

Gray, J., Janick-Buckner, D., Buckner, B., Close, P. S., and Johal, G. S. 2002. Light-dependent death of maize $l l s 1$ cells is mediated by mature chloroplasts. Plant Phys. 130:1894-1907.

Heath, M. C. 1995. Signal exchange between higher plants and rust fungi. Can. J. Bot. 73:S616-S623.

Heath, M. C. 1998. Involvement of reactive oxygen species in the response of resistant (hypersensitive) or susceptible cowpeas to the cowpea rust fungus. New Phytol. 138:251-263.

Heath, M. C. 2000. Hypersensitive response-related death. Plant Mol. Biol. 44:321-334.

Heath, M. C., and Škalamera, D. 1997. Cellular interactions between plants and biotrophic fungal parasites. Adv. Bot. Res. 24:196-224.

Heath, M. C., Nimchuk, Z., and Xu, H. 1997. Plant nuclear migrations as indicators of critical interactions between resistant or susceptible cowpea epidermal cells and invasion hyphae of the cowpea rust fungus. New Phytol. 135:689-700.

Ichinose, Y., Hisayasu, Y., Sanematsu, S., Ishiga, Y., Seki, H., Toyoda, K., Shiraishi, T., and Yamada, T. 2001. Molecular cloning and functional analysis of pea cDNA E86 encoding homologous protein to hypersensitivity-related hsr203J. Plant Sci. 160:997-1006.

Iscove, N. N., Barbara, M., Gu., M., Gibson, M., Modi, C., and Winegarden. 2002. Representation is faithfully preserved in global cDNA amplified exponentially from sub-picogram quantities of mRNA. Nature Biotechnol. 20:940-943.

Karrer, E. E., Beachy, R. N., and Holt, C. A. 1998. Cloning of tobacco genes that elicit the hypersensitive response. Plant Mol. Biol. 3:681-690.

Lambert, K. N., Ferrie, B. J., Nombela, G., Brenner, E. D., and Williamson, V. M. 1999. Identification of genes whose transcripts accumulate rapidly in tomato after root-knot nematode infection. Physiol. Mol. Plant Pathol. 55:341-348.

Latunde-Dada, A. O., and Lucas, J. A. 2001. The plant defence activator acibenzolar-S-methyl primes [Vigna unguiculata (L.) Walp.] seedlings for rapid induction of resistance. Physiol. Mol. Plant Pathol. 58:199-208.

Lin, K. C., Bushnell, W. R., Smith, A. G., and Szabo, L. J. 1998. Temporal accumulation patterns of defence response gene transcripts in relation to resistant reaction in oat inoculated with Puccinia graminis. Physiol. Mol. Plant Pathol. 52:95-114.

Ludwig, A., and Tenhaken, R. 1998. Cloning of genes by mRNA differential display induced during the hypersensitive reaction of soybean after inoculation with Pseudomonas syringae pv. glycinea. Plant Mol. Biol. 38:1225-1234.

Ludwig, A., and Tenhaken, R. 2001. A new cell wall-located N-rich protein is strongly induced during the hypersensitive response in Glycine $\max$ L. Eur. J. Plant Pathol. 107:323-326.

Matsuda, Y., Toyoda, H., Kurita, A., and Ouchi, S. 1997. In situ PCR technique based on pricking microinjection for cDNA cloning in single cells of barley coleoptile and powdery mildew pathogen. Plant Cell Reports 16:612-618.

Mellersh, D. G., and Heath, M. C. 2001. Plasma membrane-cell wall adhesion is required for expression of plant defense responses during fungal penetration. Plant Cell 13:413-424.

Mould, M. J. R., and Heath, M. C. 1999. Ultrastructural evidence of differential changes in transcription, translation, and cortical microtubules during in planta penetration of cells resistant or susceptible to rust infection. Physiol. Mol. Plant Pathol. 55:225-236.

Mur, L. A. J., Brown, I. R., Darby, R. M., Bestwick, C. S., Bi, Y.-M., Mansfield, J. W., and Draper, J. 2000. A loss of resistance to avirulent bacterial pathogens in tobacco is associated with the attenuation of a salicylic acid-potentiated oxidative burst. Plant J. 23:609-621.

Rabiti, A. L., Betti, L., Bortolotti, C., Marini, F., Canova, A., Bagni, N., and Torrigiani, P. 1998. Short-term polyamine response in TMV-inoculated hypersensitive and susceptible tobacco plants. New Phytol. 139:549-553.

Rasmussen, S., and Dixon, R. A. 1999. Transgene-mediated and elicitor induced perturbation of metabolic channeling at the entry point into the phenylpropanoid pathway. Plant Cell 11:1537-1551.

Ryerson, D. E., and Heath, M. C. 1996. Cleavage of nuclear DNA into oligonucleosomal fragments during cell death induced by fungal infection or by abiotic treatments. Plant Cell 8:393-402.

Sambrook, J., Fritsch, E. F., and Maniatis, T. 1989. Molecular Cloning: A Laboratory Manual. 2nd ed. Cold Spring Harbor Laboratory. Cold Spring Harbor, NY, U.S.A.

Škalamera, D., and Heath, M. C. 1998. Changes in the cytoskeleton accompanying infection-induced nuclear movements and the hypersensitive response in plant cells invaded by rust fungi. Plant J. 16:191-200. 
Škalamera, D., Jibodh, S., and Heath, M. C. 1997. Callose deposition during the interaction between cowpea (Vigna unguiculata) and the monokaryotic stage of the cowpea rust fungus (Uromyces vignae). New Phytol. 136:511-524.

Staskawicz, B. J. 2001. Genetics of plant-pathogen interactions specifying plant disease resistance. Plant Physiol. 125:73-76.

Tronchet, M., Ranty, B., Marco, Y., and Roby, D. 2001. HSR203 antisense suppression in tobacco accelerates development of hypersensitive cell death. Plant J. 27:115-127.

Voegele, R. T., Struck, C., Hahn, M., and Mendgen, K. 2001. The role of haustoria in sugar supply during infection of broad bean by the rust fungus Uromyces fabae. Proc. Natl. Acad. Sci. U.S.A. 98:8133-8138.

$\mathrm{Xu}, \mathrm{H}$. , and Heath, M. C. 1998. Role of calcium in signal transduction during the hypersensitive response caused by basidiospore-derived infection of the cowpea rust fungus. Plant Cell 10:585-597.

Yoda, H., Ogawa, M., Yamaguchi, Y., Koizumi, N., Kusano, T. and Sano, H. 2002. Identification of early-responsive genes associated with the hypersensitive response to tobacco mosaic virus and characterization of a WRKY-type transcription factor in tobacco plants. Mol. Genet. Gen. 267:154-161 